\title{
PENGARUH AGENCY COST TERHADAP KINERJA KEUANGAN PERUSAHAAN KELUARGA MENGGUNAKAN TOBIN'S Q \& ALTMAN Z-SCORE
}

\author{
Zainul Muchlas \\ Agus Rahman Alamsyah \\ Dosen STIE AsiA Malang
}

\begin{abstract}
Abstrak
Penelitian ini bertujuan untuk menganalisis pengaruh agency cost terhadap kinerja keuangan pada perusahaan keluarga menggunakan metode Tobin's $Q$ dan Altman Z-Score dengan variabel proksi agency cost yaitu insider ownership, dispersion ownership, institutional ownership. Penelitian dilakukan pada perusahaan keluarga sektor industri barang konsumsi yang terdaftar di Bursa Efek Indonesia periode 2011-2015. Metode yang digunakan adalah regresi linear berganda. Hasil yang diperoleh adalah agency cost (insider ownership, dispersion ownership, institutional ownership) secara simultan berpengaruh signifikan terhadap kinerja keuangan yang diukur dengan Tobin's Q, insider ownership dan institutional ownership tidak berpengaruh signifikan terhadap Tobin's Q, dispersion ownership berpengaruh signifikan terhadap Tobin's $Q$, agency cost (insider ownership, dispersion ownership, institutional ownership) secara simultan dan parsial tidak berpengaruh signifikan terhadap Altman ZScore.

Kata kunci : agency cost, perusahaan keluarga, insider ownership, dispersion ownership, institutional ownership, Tobin's Q, Altman Z-Score.
\end{abstract}

\begin{abstract}
This research aims to test the effect of agency cost toward financial performance in family business measured by Tobin's $Q$ and Altman Z-Score with proxied by insider ownership, dispersion ownership, institutional ownership. This research was conducted at family business firms listed in Indonesian Stock Exchange from 2011-2015. In this research, multiple linear regression analysis were used. The result show the agency cost (insider ownership, dispersion ownership, institutional ownership) simultaneously have a significant effect toward Tobin's $Q$, insider ownership and institutional ownership are not significant toward Tobin's $Q$, dispersion ownership has a significant effect toward Tobin's Q, agency cost (insider ownership, dispersion ownership, institutional ownership) simultaneously and partial are not significant toward Altman Z-Score.

Keywords: agency cost, family business, insider ownershop, dispersion ownership, institutional ownership, Tobin's Q, Altman Z-Score.
\end{abstract}

\section{PENDAHULUAN}

Pengelolaan perusahaan meliputi banyak aspek, pengelolaan-pengelolaan tersebut bertujuan untuk memperoleh kinerja perusahaan yang baik. Salah satu kinerja perusahaan dapat dilihat dari sisi keuangan. Penilaian kinerja perusahaan sangat berguna bagi banyak pihak, baik bagi perusahaan sendiri, investor, pemerintah, dan pihak-pihak lain yang berkepentingan. Menurut Fachrudin (2011) perhitungan kinerja perusahaan memperlihatkan kemampuan perusahaan dalam memberikan laba atas kepemilikan perusahaan berupa aset, modal maupun hutang. Di dalam perusahaan sendiri tidak lepas dari adanya permasalahan baik dari segi operasional, keuangan, pemasaran, dan lain-lain. Agency Conflict atau konflik keagenan merupakan salah satu permasalahan yang timbul. Menurut Fachrudin (2011) konflik keagenan muncul karena manajer cenderung mengambil keputusan yang bertujuan untuk menguntungkan posisinya, sedangkan hal tersebut berbeda dengan tujuan dari pemegang saham. Dari konflik keagenan menimbulkan biaya keagenan atau agency cost, yaitu memberikan insentif kepada manajer dan juga biaya pengawasan agar manajer melaksanakan fungsinya sejalan dengan tujuan pemegang saham. Penelitian-penelitian sebelumnya lebih banyak memilih perusahaan non-keluarga, tetapi pada penelitian ini penulis ingin menjadikan perusahaan keluarga sebagai objeknya. Price Waterhouse Coopper $(P w C)$, menurut Supriadi (2014), melakukan survei tentang bisnis keluarga di Indonesia yang menyebutkan bahwa $95 \%$ perusahaan di Indonesia adalah bisnis keluarga.

Tobin's Q dan Altman Z-Score merupakan salah satu metode untuk mengukur kinerja keuangan. Menurut Wolfe dan Sauia dalam Sudiyatno\& Puspitasari (2010) Tobin's Q sebagai salah satu alat untuk mengukur kinerja 
perusahaan dari perspektif investasi. Berbeda dengan Tobin's Q, Altman Z-score mengukur kinerja perusahaan yang berdampak pada potensi kebangkrutan atau potensi ketidakbangkrutan perusahaan (Altman dalam Sudiyatno dan Puspitasari, 2010). Penelitian ini juga dapat dijadikan pertimbangan bagi perusahaan untuk meningkatkan kinerja perusahaan. Bagi para investor juga dapat melihat peluang untuk berinvestasi atau potensi kebangkrutan dari suatu perusahaan keluarga di sektor industri barang konsumsi. Selain itu dari penelitian ini juga dapat melihat perilaku dari pemegang saham maupun manajer dalam menggunakan agency costs. Penelitian ini bertujuan untuk menguji secara simultan dan parsial pengaruh agency cost terhadap kinerja perusahaan keluarga yang diukur dengan Tobin's Q,juga menguji menguji secara simultan dan parsial pengaruh agency cost terhadap kinerja perusahaan keluarga yang diukur dengan Altman Z-Score, dan melihat arah perhitungan Tobin's Q dan Altman ZScore.

\section{Landasan Teori Agency Cost}

Menurut Ahmad \& Septriani (2008) perbedaan kepentingan antara pemilik perusahaan dan manajer inilah yang menyebabkan timbulnya konflik agensi. Konflik ini dapat diminimalisir dengan membuat suatu mekanisme pengawasan yang dapat mensejajarkan kepentingan dari pihak-pihak yang terkait tersebut. Mekanisme pengawasan tersebut menimbulkan biaya yang harus ditanggung perusahaan, dan biaya inilah yang menyebabkan timbulnya agency cost. Menurut Jensen \& Meckling (1976) biaya keagenan meliputi monitoring cost, bonding cost, dan residual losses.

Insider Ownership, Dispersion of Ownership, Institutional Ownership

Menurut Waruwu \& Amin (2014) fungsi dari insider ownership adalah sebagai alat pengawasan bagi manajer. Biaya yang muncul dari insider ownership berasal dari alokasi biaya kekayaan untuk perusahaan. Manajer juga cenderung untuk menggunakan utang dalam jumlah besar. Tujuannya adalah untuk kepentingan pribadi bukan untuk memaksimalkan nilai perusahaan. Tindakan tersebut memungkinkan adanya resiko kebangkrutan, karena beban bunga dari pinjaman yang tinggi sehingga agency cost dari utang yang juga akan meningkat.

Menurut Djumahir dalam Waruwu \& Amin (2014) dan dispersion of ownership adalah jumlah penyebaran kepemilikan dari seluruh saham yang dimiliki perusahaan. Sedangkan menurut Alsaeed dalam Waruwu dan Amin (2014) dispersion ownership merupakan jumlah saham yang dimiliki oleh investor secara individu di luar manajemen selain pemerintah dan lembaga-lembaga asing juga antara keluarga.

Menurut Wawuru \& Amin (2014) institutional ownership diperkirakan memiliki orientasi jangka panjang untuk investasi, karena institutional ownership bertindak sebagai pemantau perusahaan. Sedangkan menurut Wahidahwati dalam Wawuru \& Amin (2014) mengatakan bahwa institutional ownership adalah persentase saham yang dimiliki oleh badan atau institusi di luar perusahaan pada akhir tahun.

\section{Perusahaan Keluarga}

Menurut Ward \& Handy dalam Daily \& Dollinger (2001) pengklasifikasian bisnis keluarga terbagi ke dalam 2 metode yaitu kualitatif dan kuantitatif. Dalam penelitian ini, pengklasifikasian bisnis keluarga menggunakan metode kualitatif. Selain itu pengklasifikasian bisnis keluarga menurut Machek, Kolouchová, Hnilica (2015) dapat dilakukan dengan cara melihat dari nama belakang yang merupakan nama keluarga.

\section{Tobin's Q}

Tobin's Q merupakan alat ukur yang tidak asing lagi dan dianggap lebih akurat untuk mengukur nilai perusahaan yang sesungguhnya (Kusumajaya dalam Limbago dan Juniarti, 2014). Tobin Q merupakan indikator untuk mengukur kinerja perusahaan yang berhubungan dengan nilai perusahaan.

\section{Altman Z-Score}

Altman Z-score mengukur kinerja perusahaan yang berdampak pada potensi kebangkrutan atau potensi ketidakbangkrutan perusahaan (Altman dalam Sudiyatno dan Puspitasari, 2010). Pada awalnya Altman menggunakan 22 rasio yang relevan untuk memprediksi kebangkrutan. Setelah beberapa waktu Altman menghilangkan rasio-rasio yang memiliki hubungan yang kecil dengan kebangkrutan, sehingga model Altman Z-Score sekarang ini menjadi lima unsur rasio.

Penelitian Haryanti (2012) menemukan bahwa agency cost secara simultan berpengaruh signifikan terhadap nilai perusahaan, sehingga hipotesisnya adalah:

$\mathrm{H}_{\mathrm{a} 1} \quad$ : agency cost (insider ownership, dispersion ownership, institutional ownership) secara simultan berpengaruh signifikan terhadap kinerja keuangan yang diukur dengan Tobin's $\mathrm{Q}$. 
Menurut Haryanti (2012) secara parsial insider ownership berpengaruh negatif signifikan terhadap nilai perusahaan, sehingga hipotesis yang terbentuk adalah :

$\mathrm{H}_{\mathrm{a} 1.1} \quad$ : insider ownership berpengaruh signifikan terhadap kinerja keuangan yang diukur melalui Tobin's Q.

Menurut teori dispersion ownership Rahmawati (2011) mengatakan bahwa dispersion ownership yang menyebar akan menambah agency cost, dengan kata lain dispersion ownership yang tinggi akan menurunkan kinerja keuangan, sehingga hipotesisnya adalah :

$\mathrm{H}_{\mathrm{a} 1.2}$ : dispersion ownership berpengaruh signifikan terhadap kinerja keuangan yang diukur melalui Tobin's Q.

Menurut Sujoko \& Soebiantoro (2007) menemukan bahwa institutional ownership berpengaruh negatif dan signifikan terhadap nilai perusahaan, hipotesis yang terbentuk adalah sebagai berikut:

$\mathrm{H}_{\mathrm{a} 1.3} \quad$ : institutional ownership berpengaruh signifikan terhadap kinerja keuangan yang diukur melalui Tobin's Q.

Menurut Fadhilah \& Syarifuddin (2013) mengatakan bahwa agency cost berpengaruh positif dan signifikan terhadap financial distress, yang berarti apabila agency cost naik maka juga akan meningkatkan financial distress. Pada metode Altman Z-Score, potensi kebangkrutan ditunjukkan dengan nilai cut-off yaitu lebih kecil dari 1,8, sehingga hipotesis yang terbentuk adalah,

$\mathrm{H}_{\mathrm{a} 2}$ : agency cost (insider ownership, dispersion ownership, institutional ownership) secara simultan berpengaruh signifikan terhadap kinerja keuangan yang diukur dengan Altman Z-Score.

Penelitian Fadhilah \& Syafruddin (2013) menemukan bahwa insider ownership berpengaruh negatif dan signifikan terhadap financial distress, sehingga hipotesisnya adalah

$\mathrm{H}_{\mathrm{a} 2.1}$ : insider ownership berpengaruh signifikan terhadap kinerja keuangan yang diukur melalui Altman Z-Score.

Menurut teori dispersion ownership Rahmawati (2011) mengatakan dispersion ownership yang menyebar akan meningkatkan agency cost, dengan kata lain dispersion ownership yang tinggi akan menurunkan kinerja keuangan, sehingga hipotesisnya adalah,

$\mathrm{H}_{\mathrm{a} 2.2}$ : dispersion ownership berpengaruh signifikan terhadap kinerja keuangan yang diukur melalui Altman Z-Score

Menurut teori institutional ownership yang dikemukakan oleh Irwanto (2013) dan Bathala et al dalam Fauzan (2002) mengatakan bahwa semakin tinggi kepemilikan institusional maka manajemen akan tinggi pula tingkat pengawasan, hal inilah yang membuat manajemen bekerja dengan maksimal. Oleh karena itu, hipotesisnya adalah :

$\mathrm{H}_{\mathrm{a} 2.3} \quad$ : institusional ownership berpengaruh signifikan terhadap kinerja keuangan yang diukur melalui Altman Z-Score.

Menurut penelitian Chung \& Pruit (1994) pengukuran Tobin's Q memiliki hasil yaitu apabila nilai $q s>1$ maka perusahaan memiliki peluang investasi yang baik. Pada jurnal pertama, penelitian Altman (1968) menggunakan cut-off yaitu pada angka 2,675. Tetapi pada penelitian ini mengikuti cut-off dari penelitian Sudiyatno dan Puspitasari (2010) karena model pengukuran Altman terus berkembang dan dalam penelitian Sudiyatno dan Puspitasari (2010) telah disesuaikan dengan kondisi perekonomian pada sektor industri manufkatur, sehingga pengukuran Altman ZScore menurut memiliki hasil yaitu apabila nilai Z-Score > 1,8 maka perusahaan dalam keadaan sehat.

Dari teori di atas penulis menyusun $\mathrm{H}_{\mathrm{a} 3}$ sebagai berikut.

$\mathrm{H}_{3} \quad$ : Hasil perhitungan Tobin's Q searah dengan Altman Z-Score.

Metode

Penelitian ini adalah penelitian kuantitatif dengan variabel independen yaitu insider ownership, dispersion ownership, dan institutional ownership, sedangkan variabel dependen adalah Tobin's Q dan Altman ZScore. Data dalam penelitian ini adalah perusahaan keluarga sektor industri barang konsumsi yang tercatat di Bursa Efek Indonesia periode 2011-2015.Metode pengambilan sampel menggunakan purposive sampling.

Rumus perhitungan agency cost:

Insider ownership

Total shares held by the commissioners and director

Tolat shares aulistanding

Dispersion ownership

Jumlah saham dimiliki investor individu

\begin{tabular}{ll}
\hline Jurnlah sahlam yang beredar & $\times 100 \%$
\end{tabular}

Institutional awnership

Tolat shares owned by institutional investor

Tolat shares aulistanding $\times 100 \%$

Rumus Tobin's Q

$\mathrm{Q}=\mathrm{MVS}+\mathrm{D}$

TA

Keterangan :

MVS = Market value of all outstanding

shares

$\mathrm{D}=D e b t$ 
TA $\quad=$ Firm's asset's

Debt merupakan besarnya nilai pasar hutang yang dihitung sebagai berikut :

$\mathrm{D}=(\mathrm{AVCL}-\mathrm{AVCA})+\mathrm{AVLTD}$

Keterangan :

AVCL = Accounting value of the firms's current liabilities

$$
\text { = Short Term Debt }+ \text { Taxes }
$$

Payable

AVLTD $=$ Accounting value of the firm's long term debt

$\begin{array}{ll} & =\text { Long term debt } \\ \text { AVCA } & =\text { Accounting value of the }\end{array}$

firm's current assets.

$$
=\text { Cash }+ \text { Account Receivable }
$$

+ Inventories.

Setelah dihitung menggunakan rumus di atas maka berikut merupakan skor interpretasinya :

a. Tobin's q $<1$

Menggambarkan bahwa saham dalam kondisi undervalued. Manajemen telah gagal dalam mengelola aktiva perusahaan. Potensi pertumbuhan investasi rendah.

b. Tobin's $\mathrm{q}=1$

Menggambarkan bahwa saham dalam kondisi average. Manajemen tidak ada perkembangan dalam mengelola aktiva. Potensi pertumbuhan investasi tidak berkembang.

c. Tobin's q > 1

Menggambarkan bahwa saham dalam kondisi overvalued. Manajemen berhasil dalam mengelola aktiva perusahaan. Potensi pertumbuhan investasi tinggi.

\section{Altman Z-Score}

Altman Z-score mengukur kinerja perusahaan yang berdampak pada potensi kebangkrutan atau potensi ketidakbangkrutan perusahaan (Altman dalam Sudiyatno dan Puspitasari, 2010). Pada awalnya Altman menggunakan 22 rasio yang relevan untuk memprediksi kebangkrutan. Setelah beberapa waktu Altman menghilangkan rasio-rasio yang memiliki hubungan yang kecil dengan kebangkrutan, sehingga model Altman Z-Score sekarang ini menjadi lima unsur rasio. Berikut merupakan model dari persamaan dari Altman Z-score:

$Z=1,2 X_{1}+1,4 X_{2}+3,3 X_{3}+0,6 X_{4}+1,0 X_{5}$

Keterangan :

$\mathrm{Z}=$ Overall index of corporate health.

$\mathrm{X} 1=$ Working capital divided by total assets.

$\mathrm{X} 2=$ Retained earnings divided by total assets.

$\mathrm{X} 3=$ Earnings before interest and taxes divided by total assets.

$\mathrm{X} 4=$ Market value of equity divided by book value of total debt (In nonpublic organization, substitute the book value of preferred and common equity)
$\mathrm{X} 5=$ Total revenue divided by total assets.

Cut off line pada metode Altman Z-Score yaitu sebesar 1,8. Menurut Ramadhani \& Lukviarman (2009) terdapat 3 kategori penggolongan potensi kebangkrutan suatu perusahaan menurut metode Altman Z-Score, yaitu:

a. Jika nilai $\mathrm{Z}<1,8$ maka termasuk perusahaan yang berpotensi bangkrut.

b. Jika nilai $1,8<\mathrm{Z}<2,99$ maka perusahaan termasuk dalam grey area, dimana tidak dapat ditentukan apakah perusahaan tersebut berpotensi bangkrut atau tidak.

c. Jika nilai $Z>2,99$ maka perusahaan tersebut tergolong dalam perusahaan yang tidak berpotensi bangkrut.

\section{Hasil Dan Pembahasan}

Penelitian ini menggunakan metode regresi linier berganda. Setelah melakukan uji SPSS didapati data mengalami autokorelasi dan heteroskedastisitas, sehingga peneliti menggunakan $\operatorname{Lg} 10$, dan diperolah hasil sebagai berikut :

\begin{tabular}{|c|c|c|c|c|c|c|c|c|}
\hline & & $\begin{array}{l}\text { SLmo } o^{2} \\
\text { SqL ares }\end{array}$ & d1 & Nean: & cuare & t & & \\
\hline \multirow[t]{3}{*}{$\frac{\text { Wocel }}{1}$} & kecression & & & 3 & .233 & 1315 & & $6^{\mathrm{h}}$ \\
\hline & Rusicual & $\cdots$ & & $\because$ & 052 & & & \\
\hline & Tetal & . 0 & & 24 & & & & \\
\hline \multicolumn{9}{|c|}{ 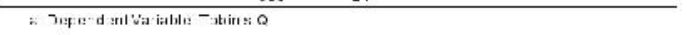 } \\
\hline \multicolumn{9}{|c|}{$\begin{array}{l}\text { E. - - redictors: } \text { :C } \\
\text { swre'ship }\end{array}$} \\
\hline \multicolumn{9}{|c|}{ Creffirienems $a^{\circ}$} \\
\hline & & \multicolumn{2}{|c|}{ 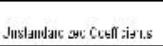 } & 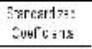 & \multirow[b]{2}{*}{ - } & \multicolumn{3}{|c|}{ C: litryait/S|s|s slits } \\
\hline \multirow[t]{5}{*}{ - 10:010 } & & $\mathrm{B}$ & $811 \mathrm{~F} \pi \mathrm{Y}$ & Fet:a & & sij & Fe anfe & $V_{F}$ \\
\hline & 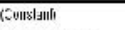 & 33 & .66 & & .296 & $\pi 0$ & & \\
\hline & irsider cer": shis & 392 & . 099 & .322 & .322 & .367 & 34. & 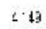 \\
\hline & c sfcrs : & .532 & $\%$ & .43 & $\Rightarrow x$ & $111 \mathrm{k}$ & $i=4$ & 13 \\
\hline & ii sli.. jurlal Jollers F F & 555 & $1.0 \mathrm{Te}$ & .132 & .516 & .611 & 237 & .225 \\
\hline
\end{tabular}

Tabel 1. Regresi Linier Berganda Y1

Sumber: Data diolah, 2017.

Dari tabel di atas diketahui agency cost secara simultan berpengaruh signifikan terhadap kinerja keuangan yang diukur dengan Tobin's Q. Secara parsial dari ketiga variabel yang signifikan terhadap kinerja keuangan yang diukur dengan Tobin's Q adalah variabel dispersion ownership.

\begin{tabular}{|c|c|c|c|c|c|c|}
\hline \multicolumn{7}{|c|}{ ANOVAC } \\
\hline Mcdel & & $\begin{array}{l}\text { Surl of } \\
\text { Squartes }\end{array}$ & df & Meall S ג ale & \multirow{2}{*}{$\frac{F}{1.042}$} & \multirow{2}{*}{$\frac{\text { Sig. }}{.395^{\mathrm{b}}}$} \\
\hline & Regression & .052 & 3 & $.32^{\prime}$ & & \\
\hline & Resicula & $.41 \varepsilon$ & 21 & . 220 & & \\
\hline & To:al & $.43 \mathrm{C}$ & 24 & & & \\
\hline \multicolumn{7}{|c|}{ an z-3zore } \\
\hline & $\begin{array}{l}\text { edictors: (Cop } \\
\text { uncrship }\end{array}$ & nsider own & $0, \mathrm{cisp}$ & son ownersh & ist tut c & \\
\hline
\end{tabular}

Tabel 2. Regresi Linier Berganda Y2 


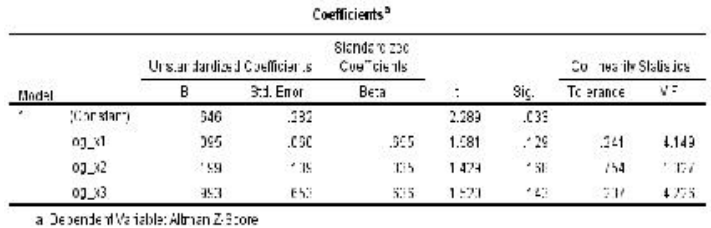

Sumber: Data diolah, 2017.

Dari tabel di atas diketahui agency cost secara simultan dan parsial tidak berpengaruh terhadap kinerja keuangan yang diukur dengan Altman Z-Score.

Tabel 3. Hasil Perhitungan Rata-Rata Tobin's Q dan Altman Z-Score

\begin{tabular}{|c|c|c|c|c|c|c|}
\hline $\mathrm{M}_{0}$ & \ama Perusahaan & Tahun & Q & Beterangan & Z & Keterangan \\
\hline$\therefore$. & $\begin{array}{l}\text { ?T Indriond CBP Subses } \\
\text { Malmur Tos }\end{array}$ & $20: 0-2014$ & 2.18 & Ses:aj & 6.54 & Sasuai \\
\hline 2. & $\begin{array}{l}\text { TI Indrind Sulses Malmur } \\
\text { Tbl } \\
\end{array}$ & $20: 0-2014$ & 0,75 & Tidak sesuai & 2,36 & Groy:5018 \\
\hline 3. & PT Mavoo:asdah Tós & $20: 0-2014$ & 2,16 & Ses_aj & 5,25 & Szsuai \\
\hline 4. & IT Pra idca Aneka Niage & $20: 0-2014$ & 0,32 & Tidak sesuai & 285 & Grey:00:8 \\
\hline 5. & PT Sizr.tar Top & 20:0-2014 & 1,15 & Ses.aj & 3,61 & Sesvuai \\
\hline 6. & 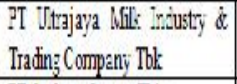 & $20: 0-2014$ & 1.65 & Sešaj & 5,54 & Sesuai \\
\hline$?$ & PT Cudaną Garam Tos & 20:0-2014 & 183 & Sessaj & 5,56 & Sesual \\
\hline 8. & $\begin{array}{l}\text { PT Langegeng Vhamur Industi } \\
\text { Tbl }\end{array}$ & $20: 0-2014$ & 0,28 & Tidak sesval & .93 & Grey:-00:3 \\
\hline \multicolumn{3}{|c|}{ Frail Rata-Rata Seluruh Perusahaan } & 1,29 & Sesuai & 4,2 & Sesuai \\
\hline
\end{tabular}

Sumber: Data diolah, 2017

Keterangan :

a. Sesuai : melewati nilai cut-off atau berada di atas nilai cut-off dari masingmasing metode yaitu pada model Tobin's Q dan Altman Z-Score.

b. Tidak Sesuai : tidak melewati nilai cut-off atau berada di bawah nilai cut-off dari masing-masing metode yaitu pada model Tobin's Q dan Altman Z-Score.

c. Grey-Zone : kriteria ini berlaku untuk perhitungan Altman Z-Score dimana kondisi ini menunjukkan bahwa perusahaan tidak bisa ditentukan apakah berpotensi untuk mengalami kebangkrutan atau tidak.

\section{Pengujian Hipotesis}

Pengaruh agency cost (insider ownership, dispersion of ownership, institutional ownership) secara simultan dan parsial terhadap kinerja keuangan pada perusahaan keluarga sektor industri barang konsumsi di BEI diukur dengan Tobin's Q.

Agency cost yang diproksikan melalui insider ownership, dispersion of ownership, institutional ownership secara simultan berpengaruh signifikan terhadap Tobin's Q. Hasilnya dinyatakan signifikan, sehingga $\mathrm{H}_{\mathrm{a} 1}$ diterima. Hal ini sejalan dengan penelitian Haryanti (2012) yang mengatakan bahwa secara simultan agency cost berpengaruh signifikan terhadap nilai perusahaan.

Pengaruh insider ownership terhadap kinerja keuangan pada perusahaan keluarga sektor industri barang konsumsi di BEI diukur dengan Tobin's $\mathbf{Q}$.

Dilihat dari Tabel 1, variabel insider ownership tidak signifikan terhadap kinerja keuangan yang diukur dengan Tobin's Q. Hal ini tidak sejalan dengan penelitian Haryanti (2012) yang mengatakan bahwa agency cost dengan proksi insider ownership berpengaruh negatif signifikan terhadap nilai perusahaan. Bila dikaitkan dengan teori, menurut Ahmad \& Septriani (2008) hasil dari penelitian ini sesuai karena, menurut teori semakin banyak insider ownership maka dapat mengurangi agency cost, dengan berkurangnya agency cost maka kemungkinan besar nilai perusahaan akan meningkat karena biaya yang mengecil akan meningkatkan laba dan akan menguntungkan bagi investor. Dari hasil ini dapat disimpulkan bahwa $\mathrm{H}_{\mathrm{a} 1.1}$.

Pengaruh dispersion of ownership terhadap kinerja keuangan pada perusahaan keluarga sektor industri barang konsumsi di BEI diukur dengan Tobin's $\mathbf{Q}$.

Secara parsial dispersion ownership berpengaruh signifikan terhadap kinerja keuangan yang diukur dengan Tobin's Q. Dinyatakan bahwa $\mathrm{H}_{\mathrm{a} 1.2}$ diterima dan $\mathrm{H}_{01.2}$ ditolak. Hal ini sejalan dengan teori menurut Rahmawati (2011) yang mengatakan bahwa semakin tinggi angka dispersion ownership maka akan semakin meningkatkan agency cost. Pengaruh negatif antara dispersion ownership dengan kinerja keuangan melalui Tobin's Q menunjukkan bahwa apabila dispersion ownership meningkat maka akan menurunkan kinerja keuangan melalui Tobin's Q.

Pengaruh institutional ownership terhadap kinerja keuangan pada perusahaan keluarga sektor industri barang konsumsi di BEI diukur dengan Tobin's $\mathbf{Q}$.

Institutional ownership tidak berpengaruh signifikan terhadap kinerja keuangan yang diukur dengan Tobin's Q. Maka pada penelitian ini $\mathrm{H}_{a 1.3}$ ditolak. Hasil dari penelitian ini sejalan dengan teori menurut Ahmad \& Septriani (2008) yang mengatakan bahwa institutional ownership merupakan salah satu cara yang dapat digunakan untuk mengurangi agency cost karena dengan semakin banyak kepemilikan saham oleh institusi di luar perusahaan maka akan meningkatkan pengawasan yang lebih optimal bagi manajemen.Apabila institutional ownership meningkat maka juga akan 
meningkatkan kinerja perusahaan yang diukur menggunakan Tobin's Q.

Pengaruh agency cost (insider ownership, dispersion of ownership, institutional ownership) secara simultan terhadap kinerja keuangan pada perusahaan keluarga sektor industri barang konsumsi di BEI diukur dengan Altman Z-Score.

Dari Tabel 2 menunjukkan bahwa dari hasil uji simultan, agency cost tidak berpengaruh signifikan terhadap kinerja keuangan yang diukur dengan Altman Z-Score. Angka sig. pada uji $\mathrm{F}$ adalah 0,395 yang berarti $>$ 0,05. Dari hasil tersebut, maka secara simultan $\mathrm{H}_{\mathrm{a} 2}$ ditolak. Hal ini sejalan dengan penelitian Agustina, Rifa \& Meihendri (2015) yang melihat pengaruh agency cost terhadap financial distress, dengan hasil agency cost berpengaruh positif tidak signifikan terhadap financial distress.Financial distress merupakan keadaan penurunan keuangan perusahaan yang terjadi sebelum kebangkrutan atau likuidasi. Dari definisi tersebut diketahui bahwa financial distress dan Altman Z-Score sama-sama membahas tentang potensi kebangkrutan suatu perusahaan.

Pengaruh insider ownership terhadap kinerja keuangan pada perusahaan keluarga sektor industri barang konsumsi di BEI diukur dengan Altman Z-Score.

Secara parsial variabel insider ownership tidak berpengaruh signifikan terhadap kinerja keuangan yang diukur melalui Altman Z-Score. Hasil ini sejalan dengan penelitian Sastriana (2013) yang mengatakan bahwa kepemilikan manajerial tidak berpengaruh signifikan terhadap financial distress. Dengan demikian hasil ini menolak $\mathrm{H}_{\mathrm{a} 2.1}$ dan $\mathrm{H}_{02.1}$ diterima. Menurut Xiaolan \& Zongjun dalam Ayuningtias (2013) mengatakan bahwa insider ownership digunakan sebagai simbol saja yang kemudian dapat menarik perhatian investor. Pada umumnya investor lebih tertarik dengan perusahaan yang memiliki insider ownership karena dengan adanya insider ownership akan meningkatkan nilai dari perusahaan karena adanya pengelola perusahaan yang ikut memiliki perusahaan tersebut.

Pengaruh dispersion of ownership terhadap kinerja keuangan pada perusahaan keluarga sektor industri barang konsumsi di BEI diukur dengan Altman Z-Score.

Secara parsial dispersion ownership tidak berpengaruh signifikan terhadap kinerja keuangan yang diukur dengan Altman Z-Score. Hasil penelitian ini menolak $\mathrm{H}_{\mathrm{a} 2.2}$. Hasil penelitian ini tidak sesuai dengan teori tentang dispersion ownership yang dikemukakan oleh
Rahmawati (2011) yang mengatakan bahwa apabila dispersion ownership meningkat maka akan meningkatkan juga agency cost.

Pengaruh institutional ownership terhadap kinerja keuangan pada perusahaan keluarga sektor industri barang konsumsi di BEI diukur dengan Altman Z-Score.

Institutional ownership secara parsial tidak berpengaruh terhadap kinerja keuangan yang diukur melalui Altman Z-Score. Hasil ini sejalan dengan penelitian Wardhani (2007) yang mengatakan bahwa institutional ownership yang ada dalam perusahaan tidak merubah kemungkinan untuk suatu perusahaan mengalami tekanan keuangan. Oleh karena itu, dapat disimpulkan bahwa hasil ini menolak $\mathrm{H}_{\mathrm{a} 2.3}$.

Perbandingan Hasil Perhitungan Tobin's Q dan Altman Z-Score

Bila dilihat pada Tabel 3. bahwa nilai $Q$ adalah 1,29 dan nilai $Z$ adalah 4,2. Nilai $Q>1$ dapat dikatakan bahwa secara keseluruhan perusahaan keluarga yang digunakan sebagai sampel dalam penelitian ini memiliki potensi investasi yang baik. Nilai Z $>2,99$ dapat dikatakan bahwa secara keseluruhan perusahaan keluarga yang digunakan sebagai sampel dalam penelitian ini tidak berpotensi untuk mengalami kebangkrutan. Sehingga dalam penelitian ini $\mathrm{H}_{\mathrm{a} 3}$ diterima.

\section{Simpulan Dan Saran}

Agency cost secara simultan berpengaruh signifikan terhadap kinerja keuangan yang diukur dengan Tobin's Q, dispersion ownership juga berpengaruh signifikan terhadap kinerja keuangan yang diukur dengan Tobin's Q, dan juga hasil perhitungan Tobin's Q searah dengan Altman Z-Score. Institutional ownership dan dispersion ownership secara parsial tidak berpengaruh signifikan terhadap kinerja keuangan yang diukur dengan Tobin's Q. Agency cost secara simultan dan parsial tidak berpengaruh signifikan terhadap kinerja keuangan yang diukur dengan Altman Z-Score. Perusahaan keluarga dalam penelitian ini dapat mempertahankan dan juga meningkatkan kinerja perusahaannya. Bagi calon investor dapat lebih teliti melihat perilaku baik dari pemegang saham maupun manajer puncak yang akan berdampak pada kinerja keuangan. Bagi penelitian selanjutnya dapat lebih memperluas sampel penelitian sehingga hasil yang di dapat lebih menyeluruh.

\section{DAFTAR PUSTAKA}

1. Agustina, N., Rifa, D., \& Meihendri. (2015). Pengaruh Agency Cost, Corporate Governance Dan Profitabilitas Terhadap Financial Distress. E-Jurnal Bung Hatta, 7(1), 1-12.

2. Ahmad, A. W., \& Septriani, Y. (2008). Konflik Keagenan: Tinjauan Teoritis dan Cara 
Menguranginya. Jurnal Akuntansi \& Manajemen, 3(2), 47-55.

3. Altman, E. I. (1968). Finantial Ratios, Discriminant Analysis and The Prediction of Bankruptcy. The Journal of Finance, 23(4), 589-609.

4. Ayuningtias. (2013). Analisis Pengaruh Struktur Kepemilikan, Board Composition, Dan Agency Cost Terhadap Financial Distress. Jurnal Ilmu Manajemen Universitas Negeri Surabaya, 1(1), 1-14.

5. Chung, K. H., \& Pruitt, S. W. (1994). A Simple Approximation of Tobin's Q. Financial Management, 23(3), 70-74.

6. Daily, C. M., \& Dollinger, M. J. (2001). Alternative Methodologies For Indetifying Family Versus NonFamily-Managed Business. Journal of Small Business Management, 79-90.

7. Fachrudin, K. A. (2011, Mei). Analisis Pengaruh Struktur Modal, Ukuran Perusahaan, dan Agency Cost Terhadap Kinerja Perusahaan. Jurnal Akuntansi dan Keuangan, 13(1), 37-46.

8. Fadhilah, F. N., \& Syafruddin, M. (2013). Analisis Pengaruh Karakterisitik Corporate Governance Terhadap Kemungkinan Financial Distress. Jurnal Akuntansi, 2(2), 1-15.

9. Fauzan. (2002, September). Hubungan Biaya Keagenan, Resiko Pasar dan kesempatan Investasi dengan Kebijakan Deviden. Jurnal Akuntansi dan Keuangan, 1(2), 114-138.

10. Haryanti. (2012). Pengaruh "Agency Cost" Terhadap Nilai Perusahaan Dengan Kebijakan Dividen Dan Struktur Modal Sebagai Variabel Intervening. Jurnal Probank, 20(24), 1-24.

11. Irwanto, A. (2013). Pengaruh Kepemilikan Institusional Terhadap Financial Distress. E-journal Unesa, 1-14. Jensen, M., \& Meckling, W. H. (1976). Theory Of The Firm: Managerial Behavior, Agency Cost And Ownership Structure. Journal of Financial Economics, 3, 305-360.

12. Limbago, E., \& Juniarti. (2014). Pengaruh Family Control Terhadap Profitabilitas dan Nilai Perusahaan Pada Industri Properti dan Real Estate. studentjournal.petra.ac.id.Machek, O., Kolouchová, D., \& Hnilica, J. (2015). Identifying Family Businesses: The Surname Matching Approach. Journal Recent Advances in Environmental and Earth Sciences and Economics, 96-100.

13. Rahmawati, C. H. (2011). Pengaruh Insider Ownership, Institutional Ownership, Dispersion Of Ownership,
Tingkat Pertumbuhan Perusahaan, Dan Risiko Perusahaan Terhadap Kebijakan Dividen Pada Perusahaan Yang Terdaftar Di Bursa Efek Indonesia Periode 20032006. Jurnal Widya Warta, 1-18.

14. Ramadhani, A. S., \& Lukviarman, N. (2009, April). Perbandingan Analisis Prediksi Kebangkrutan Mengggunakan Model Altman Pertama, ALtman Revisi, Dam ALtman Modifikasi Dengan Ukuran Dan Umur Perusahaan Sebagai Variabel penjelas (Studi Pad Perusahaan Manufaktur Yang Terdaftar Di Bursa Efek Indonesia). Jurnal Siasat Bisnis, 13(1), 1528.

15. Sudiyatno, B., \& Puspitasari, E. (2010). Tobin's Q Dan Altman Z-Score Sebagai Pengukuran Kinerja Perusahaan. Jurnal Kajian Akuntansi, 9-21.

16. Sujoko, \& Soebiantoro, U. (2007). Pengaruh Struktur Kepemilikan Saham, Leverage, Faktor Intern Dan Faktor Ekstern Terhadap Nilai Perusahaan (Studi empirik pada perusahaan manufaktur dan non manufaktur di Bursa Efek Jakarta). Jurnal Manajemen Dan Kewirausahaan, 9(1), 41-48.

17. Supriadi, A. (2014, Desember 2). PwC: 95 Persen Perusahaan Indonesia Adalah Bisnis Keluarga. Retrieved Mei 21, 2015, from www.cnnindonesia.com: http://www.cnnindonesia.com/ekonomi/20 141202100356-92-15176/pwc-95-persenperusahaan-indonesia-adalah-bisniskeluarga/

18. Wardhani, R. (2007). Mekanisme Corporate Governanve Dalam Perusahaan Yang Mengalami Permasalahan Keuangan. Jurnal Akuntansi dan Keuangan Indonesia, 4(1), 95-114.

19. Waruwu, J. M., \& Amin, M. N. (2014, Februari). Pengaruh Agency Costs Dan Siklus Hidup Perusahaan Terhadap Kebijakan Dividen Pada Perusahaan Terdaftar Di Bursa Efek Indonesia Tahun 2009-2011. E-Journal Akuntansi, 1(1). 